\title{
Uranium isotopes as a tracer of groundwater transport studies
}

\author{
P. Grabowski • H. Bem
}

Received: 10 November 2011 / Published online: 17 December 2011

(C) The Author(s) 2011. This article is published with open access at Springerlink.com

\begin{abstract}
The activity concentrations of ${ }^{234} U$ and ${ }^{238} U$ in thermal groundwater, deep well water and river water samples from Central Poland were determined. Concentration of ${ }^{234} \mathrm{U}$ and ${ }^{238} \mathrm{U}$ in the examined waters varied from $<0.013$ (LLD) to $16.8 \mathrm{mBq} / \mathrm{dm}^{3}$ and from $<0.013$ (LLD) to $45.5 \mathrm{mBq} / \mathrm{dm}^{3}$ respectively. The highest uranium activity concentrations were measured in the thermal groundwater from Mszczonow and Cieplice, while the lowest were observed in thermal ground water from Uniejow and Poddebice. In thermal groundwater from Skierniewice, uranium activity concentrations were below lower limit of detection $\left(0.013 \mathrm{mBq} / \mathrm{dm}^{3}\right)$. The ${ }^{234} \mathrm{U} /{ }^{238} \mathrm{U}$ activity ratio varied from 0.37 (Cieplice) to 1.30 (Poddebice well water).
\end{abstract}

Keywords Uranium radionuclide $\cdot{ }^{234} \mathrm{U} /{ }^{238} \mathrm{U}$ activity ratio - Alpha spectrometry $\cdot$ Thermal groundwater

\section{Introduction}

Uranium chain radionuclides are usually used for a wide range of applications in the Earth Sciences. The ${ }^{234} \mathrm{U} /{ }^{238} \mathrm{U}$ activity ratio is used as a geochemical tool to investigate transport and flow relationships in major hydrological reservoirs, groundwater pattern and it is highly useful for interpreting timescales of weathering. In rocks older than a few million years, ${ }^{234} \mathrm{U} /{ }^{238} \mathrm{U}$ activity ratios should be in secular equilibrium [1]. Many studies on ${ }^{238} U$ and ${ }^{234} U$ in natural waters indicate that these isotopes occur in a disequilibrium state and that, with a few exceptions, water samples contain

P. Grabowski · H. Bem $(\square)$

Department of Chemistry, Technical University of Lodz,

Żeromskiego Street 116, 90-924 Lodz, Poland

e-mail: henryk.bem@p.lodz.pl higher ${ }^{234} \mathrm{U}$ activities than ${ }^{238} \mathrm{U}[2-4]$. The higher activity of ${ }^{234} \mathrm{U}$ in waters is the result of the ${ }^{234} \mathrm{U}$ atom displacement from the crystal lattice after ${ }^{238} \mathrm{U}$ decay and recoil of the formed ${ }^{234} \mathrm{Th}$ nuclide, which after two consecutive decays finally form the ${ }^{234} \mathrm{U}$ nuclide. It allows ${ }^{234} \mathrm{U}$ to be more mobile during the weathering of rocks by atmospheric water. The recoil ${ }^{234} \mathrm{U}$ atoms are liable to be oxidized to the hexavalent stage and can be leached into the water phase more easily than its parent nuclide ${ }^{238} \mathrm{U}$. The oxidation of $\mathrm{U}(\mathrm{IV})$ to $\mathrm{U}(\mathrm{VI})$ is an important step in leaching into water, because compounds of $\mathrm{U}(\mathrm{VI})$ have a higher solubility in water $[2,3,5,6]$. The uranium isotope ratio is also influenced by other factors: the age of the rocks, rock type and climate difference [1]. This fact has been successfully applied for geological tracing or the characterization of geochemical processes.

In the same way, the ${ }^{235} \mathrm{U} /{ }^{238} \mathrm{U}$ isotope ratio (natural value $7.25 \times 10^{-3}$ ) has been used for the identification of anthropogenic pollution scenarios [7,8]. ${ }^{235} \mathrm{U}$ is a key isotope in nuclear fuel manufacture and reprocessing, and any deviation from the expected natural isotope ratio in environmental samples is an indication of contamination from nuclear activity. Large increases in the ${ }^{236} \mathrm{U} /{ }^{238} \mathrm{U}$ isotopic ratio represent have been used as a clear indicator of the presence of irradiated uranium $[8,9]$.

Average ${ }^{238} \mathrm{U}$ and ${ }^{234} \mathrm{U}$ activity concentrations in surface and ground water are in the range from 1 to $20 \mathrm{mBq} / \mathrm{dm}^{3}$ [10]. A major source of uranium is seawater, where its average concentration of ${ }^{238} \mathrm{U}$ equal to $41.5 \mathrm{mBq} / \mathrm{dm}^{3}$ [11]. The highest uranium activity concentrations were detected in the drinking water in a private well in Finland $-150 \mathrm{~Bq} / \mathrm{dm}^{3}[12]$.

The uranium activity ratio can be measured in diverse matrices by radiometric, mass spectrometry and alpha spectrometry methods. Advances in the methods of uranium activity ratio determination have been recently overviewed [13-15]. 
Fig. 1 Location of sampling collection sites

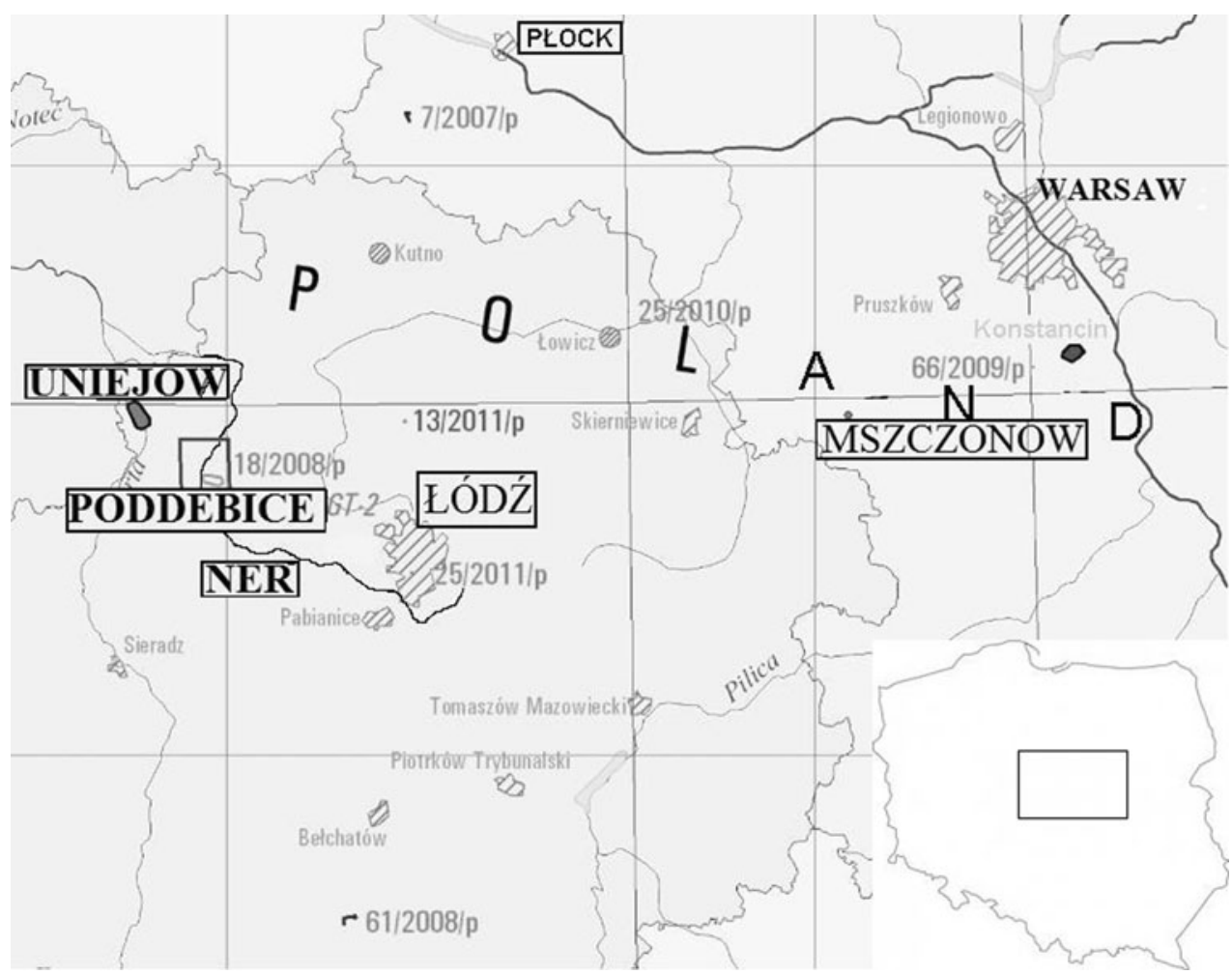

Recently we have found significant differences in the some natural radionuclide activity concentrations in deep well water samples (including thermal groundwater) originating basically from the same Lower Cretaceous geological formation [16]. Since the salinity of these samples differs also substantially one possible explanation for this phenomenon is the possible infiltration of surface water to these underground reservoirs. Special attention has been devoted to a newly exploited source of the thermal groundwater from Poddebice close to the city of Lodz. In very close vicinity of this thermal groundwater source lying 2,000 m below ground level, there are two other important water sources: an underground water reservoir (70 $\mathrm{m}$ below surface) used as a source of municipal drinking water, and the Ner river. The Ner river flows mostly through the rural area, and the main source of uranium in its water should be the dissolved uranium from fertilizers.

Therefore, it seems to be interesting to compare the uranium activity ratio in the selected water samples in order to detect the possible vertical transport of the surface water to the deep underground thermal water reservoir.

\section{Experimental}

Study area

Samples of thermal groundwater, groundwater and surface water was collected from different sites from central Poland (Fig. 1).

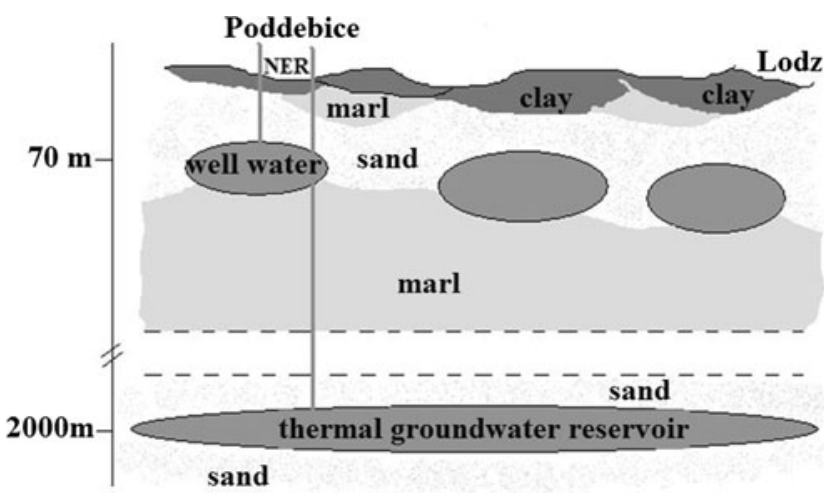

Fig. 2 Sites of samples collection in Poddebice

In the case of Poddebice, the water samples were taken from three water sources:

(a) The Ner river

(b) Well municipal water (70 $\mathrm{m}$ below surface)

(c) Thermal groundwater reservoir $(2,000 \mathrm{~m})$ as is shown in Fig. 2.

Ten litres of each water sample were collected in polyethylene bottles with screw caps. All samples were acidified to $\mathrm{pH} \approx 2$ directly after collection. As the water samples presented complete clarity, filtering of the samples was considered unnecessary.

For the Poddebice sites, several soil samples from different levels of the bore-hole were also taken for uranium radionuclides analysis. 
Table 1 The results of ${ }^{234} \mathrm{U}$ and ${ }^{238} \mathrm{U}$ activity in International Atomic Energy Agency (IAEA) samples

\begin{tabular}{llllll}
\hline Sample & ${ }^{234} \mathrm{U}$ & & & ${ }^{238} \mathrm{U}$ & \\
\cline { 2 - 3 } \cline { 5 - 6 } & $\begin{array}{l}\text { IAEA value } \\
(\mathrm{Bq} / \mathrm{kg})\end{array}$ & $\begin{array}{l}\text { Measured } \\
\text { value }(\mathrm{Bq} / \mathrm{kg})\end{array}$ & $\begin{array}{l}\text { IAEA value } \\
(\mathrm{Bq} / \mathrm{kg})\end{array}$ & $\begin{array}{l}\text { Measured } \\
\text { value }(\mathrm{Bq} / \mathrm{kg})\end{array}$ \\
\hline 1 & $0.04 \pm 0.00$ & $<\mathrm{LLD}$ & & $0.04 \pm 0.00$ & $<\mathrm{LLD}$ \\
2 & $1.30 \pm 0.03$ & $1.29 \pm 0.02$ & & $0.70 \pm 0.02$ & $0.69 \pm 0.02$ \\
3 & $0.47 \pm 0.01$ & $0.47 \pm 0.02$ & & $0.31 \pm 0.01$ & $0.29 \pm 0.02$ \\
\hline
\end{tabular}

\section{Radiochemical method}

Uranium isotopes were co-precipitated from water samples with hydrated manganese dioxide by a method described elsewhere [17-19].

Hydrated manganese dioxide was dissolved in $50 \mathrm{~mL}$ of $3 \% \mathrm{H}_{2} \mathrm{O}_{2}$ in $1 \mathrm{M} \mathrm{HCl}$ solution and evaporated to dryness. The residue was dissolved in $50 \mathrm{~mL}$ of $9 \mathrm{M} \mathrm{HCl}$ and was passed through the anion exchangeable resin Dowex 1X8 (50-100 mesh, $\mathrm{Cl}^{-}$form). Each column was first conditioned by $50 \mathrm{~mL} 9 \mathrm{M} \mathrm{HCl}$. Under this condition, uranium is adsorbed by the resin, whereas thorium and other elements are passed with the solution and discarded [20]. Then the column was washed with $20 \mathrm{~mL}$ of $9 \mathrm{M} \mathrm{HCl}$ to eliminate residual thorium traces. Cations of $\mathrm{U}^{+4}, \mathrm{U}^{+6}$ and $\mathrm{Fe}^{+3}$ were retained on the column. Iron ion was eluted with $25 \mathrm{~mL}$ of $8 \mathrm{M} \mathrm{HNO}_{3}$. The remaining uranium was eluted in two portion: with $25 \mathrm{~mL}$ of $8 \mathrm{M}$ $\mathrm{HNO}_{3}$ and with $50 \mathrm{~mL}$ deionized water, and the total collected solution was evaporated. After evaporation the solid residue containing uranium was dissolved in $0.75 \mathrm{M}$ $\left(\mathrm{NH}_{4}\right)_{2} \mathrm{SO}_{4}$ solution and then it was transferred to an electrolytic cell. Uranium isotopes $\left({ }^{234} \mathrm{U}\right.$ and $\left.{ }^{238} \mathrm{U}\right)$ are electrodeposited on a stainless steel disc at a current density of $1.2 \mathrm{~A} / \mathrm{cm}^{2}$ for $1.5 \mathrm{~h}$. Fifteen minutes before ending the electrolysis, $0.5 \mathrm{~mL} \mathrm{NH}_{4} \mathrm{OH}$ solution was added to the electrolyte to complete the uranium deposition on the disk. The disk with uranium was washed with deionized water and acetone.

The activity concentrations of uranium isotopes were determined using an $\alpha$ spectrometry system with PIPS detector (Canberra Packard). Lower limit of detection, for $300,000 \mathrm{~s}$ counting time, were equal to $0.013 \mathrm{mBq} / \mathrm{dm}^{3}$ for each of the uranium isotopes.

The activity concentrations of ${ }^{238} \mathrm{U}$ via its daughter ${ }^{234} \mathrm{Th}$ in the soil samples were determined by gamma spectrometry with HPGe detector using its principal $\gamma$-line $63.3 \mathrm{keV}$.

Quality assurance of the elaborated method

The accuracy of the developed method for uranium determination was evaluated by checking the activity concentration of ${ }^{234} U$ and ${ }^{238} U$ in two Standard Reference Materials: IAEA Soil 327, IAEA Phosphogypsum 434 and IAEA water samples distributed for intercomparison measurementsCU-2010-03. The average uranium recovery was almost quantitatively (varied from 92 to 100\%). The results for intercomparison measurements-CU-2010-03 are presented in Table 1.

\section{Results and discussion}

Activity concentration of uranium isotopes in Poddebice region

The activity concentration of ${ }^{234} U$ and ${ }^{238} U$ in the water samples taken from three sources around the geothermal bore-hole of Poddebice in different months of 2011 are presented in Table 2.

Table 2 Activity concentration of ${ }^{234} \mathrm{U}$ and ${ }^{238} \mathrm{U}$ in thermal groundwater, well water and river water from Poddebice $\left(\mathrm{mBq} / \mathrm{dm}{ }^{3}\right)$

\begin{tabular}{|c|c|c|c|c|c|c|c|c|c|c|c|c|}
\hline \multirow{3}{*}{$\begin{array}{l}\text { Months } \\
\text { January }\end{array}$} & \multicolumn{4}{|c|}{ Geothermal reservoir } & \multicolumn{4}{|c|}{ River water-NER } & \multicolumn{4}{|c|}{ Well water Poddębice } \\
\hline & \multicolumn{2}{|l|}{$\overline{{ }^{234} \mathrm{U}}$} & \multicolumn{2}{|l|}{${ }^{238} \mathrm{U}$} & \multicolumn{2}{|l|}{${ }^{234} \mathrm{U}$} & \multicolumn{2}{|l|}{${ }^{238} \mathrm{U}$} & \multicolumn{2}{|l|}{${ }^{234} \mathrm{U}$} & \multicolumn{2}{|l|}{${ }^{238} \mathrm{U}$} \\
\hline & na & & na & & 8.54 & \pm 0.19 & 7.96 & \pm 0.18 & 4.12 & \pm 0.13 & 4.17 & \pm 0.13 \\
\hline February & 0.151 & \pm 0.025 & 0.159 & \pm 0.026 & 6.95 & \pm 0.17 & 6.36 & \pm 0.16 & 1.29 & \pm 0.07 & 1.23 & \pm 0.08 \\
\hline March & 0.110 & \pm 0.021 & 0.119 & \pm 0.022 & 5.16 & \pm 0.15 & 5.05 & \pm 0.14 & 0.79 & \pm 0.06 & 0.83 & \pm 0.06 \\
\hline April & 0.102 & \pm 0.020 & 0.106 & \pm 0.021 & 4.83 & \pm 0.16 & 4.31 & \pm 0.15 & 1.19 & \pm 0.07 & 0.92 & \pm 0.06 \\
\hline May & 0.168 & \pm 0.026 & 0.176 & \pm 0.027 & 5.03 & \pm 0.14 & 4.66 & \pm 0.14 & 0.97 & \pm 0.07 & 0.82 & \pm 0.07 \\
\hline June & 0.087 & \pm 0.020 & 0.092 & \pm 0.021 & 4.78 & \pm 0.15 & 3.98 & \pm 0.14 & 1.73 & \pm 0.12 & 1.92 & \pm 0.13 \\
\hline July & 0.037 & \pm 0.012 & 0.041 & \pm 0.013 & 3.09 & \pm 0.12 & 2.83 & \pm 0.11 & 1.65 & \pm 0.08 & 1.62 & \pm 0.08 \\
\hline August & 0.049 & \pm 0.014 & 0.053 & \pm 0.014 & 4.35 & \pm 0.14 & 3.76 & \pm 0.13 & 0.45 & \pm 0.04 & 0.43 & \pm 0.04 \\
\hline September & 0.064 & \pm 0.014 & 0.071 & \pm 0.015 & 3.23 & \pm 0.11 & 2.84 & \pm 0.10 & 0.62 & \pm 0.05 & 0.70 & \pm 0.05 \\
\hline October & 0.123 & \pm 0.019 & 0.132 & \pm 0.020 & 1.43 & \pm 0.07 & 1.15 & \pm 0.06 & 0.85 & \pm 0.05 & 0.82 & \pm 0.05 \\
\hline
\end{tabular}

na Not analyzed 
Fig. 3 Activity concentration of ${ }^{234} \mathrm{U}$ and ${ }^{238} \mathrm{U}$ in the Ner river
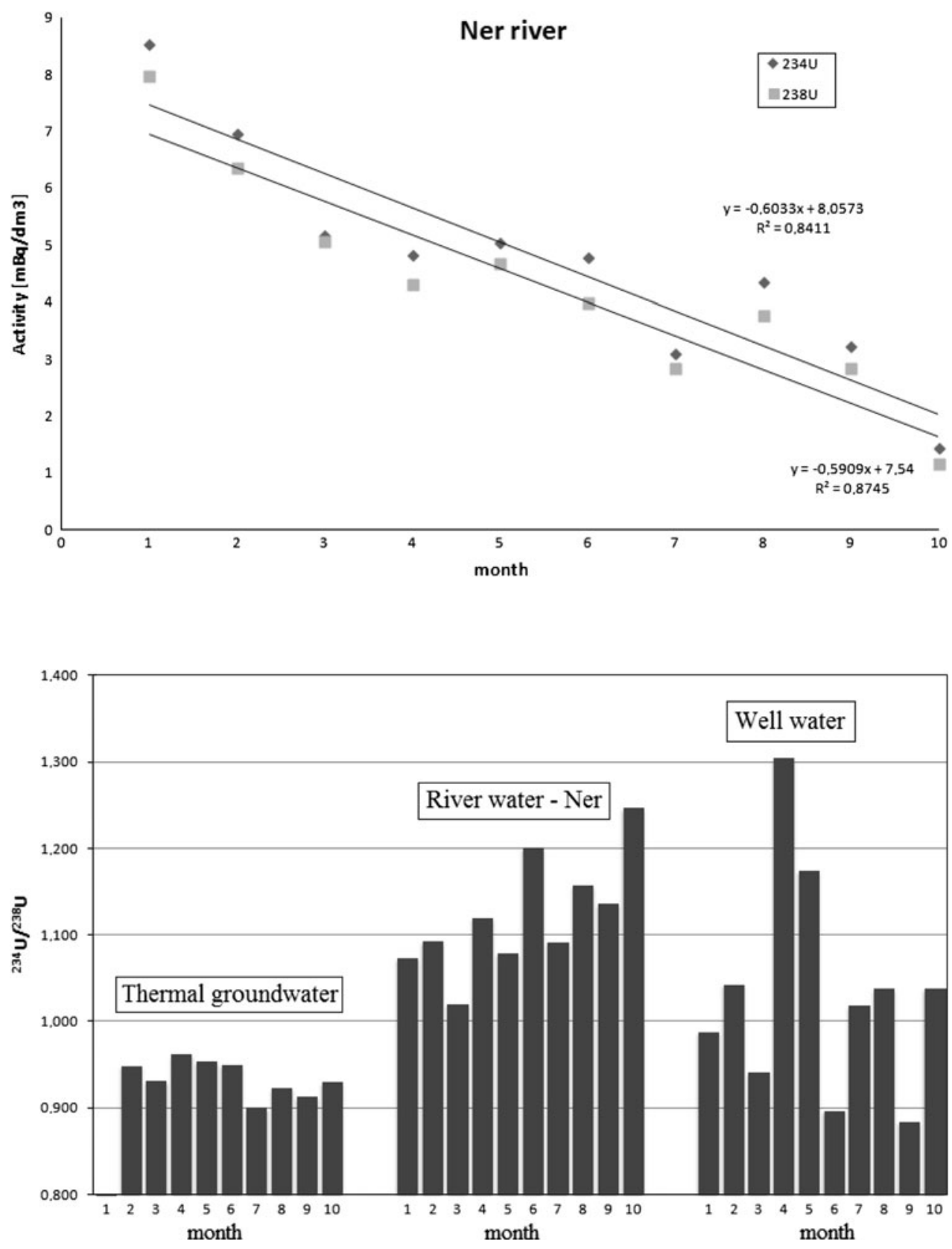

Fig. 4 Uranium isotopic ratio $\left({ }^{234} \mathrm{U} /{ }^{238} \mathrm{U}\right)$ in thermal groundwater, deep well water and river water from Poddebice
The lowest activity concentration of ${ }^{234} U$ and ${ }^{238} U$ were found in the thermal groundwater samples, and varied from 0.087 to $0.168 \mathrm{mBq} / \mathrm{dm}^{3}$ and from 0.092 to $0.176 \mathrm{mBq} /$ $\mathrm{dm}^{3}$ for ${ }^{234} \mathrm{U}$ and ${ }^{238} \mathrm{U}$ respectively. As expected, the highest contents of uranium isotopes were found in the river water, from the Ner, as a result of additional anthropogenic uranium input from agricultural application of phosphoric fertilizer [21]. In this water activity, concentrations varied from 1.43 to $8.54 \mathrm{mBq} / \mathrm{dm}^{3}$ and from 1.15 to $7.96 \mathrm{mBq} / \mathrm{dm}^{3}$ for ${ }^{234} \mathrm{U}$ and ${ }^{238} \mathrm{U}$ respectively.

The slight seasonal decrease of uranium concentration in the Ner river, connected with periods of rain, can be also observed (Fig. 3). Similar levels of ${ }^{238} \mathrm{U}$ activity concentration and its seasonal fluctuation were observed for other Polish main rivers [21, unpublished data].

${ }^{234} \mathrm{U} /{ }^{238} \mathrm{U}$ isotopic ratio in Poddebice region

As was mentioned, the interesting information concerning mutual transfer between underground and surface water can be obtained from a comparison of ${ }^{234} \mathrm{U} /{ }^{238} \mathrm{U}$ activity ratio in these water samples. The results of the seasonal fluctuations of ${ }^{234} \mathrm{U} /{ }^{238} \mathrm{U}$ in water samples from Poddebice are shown in Fig. 4. 


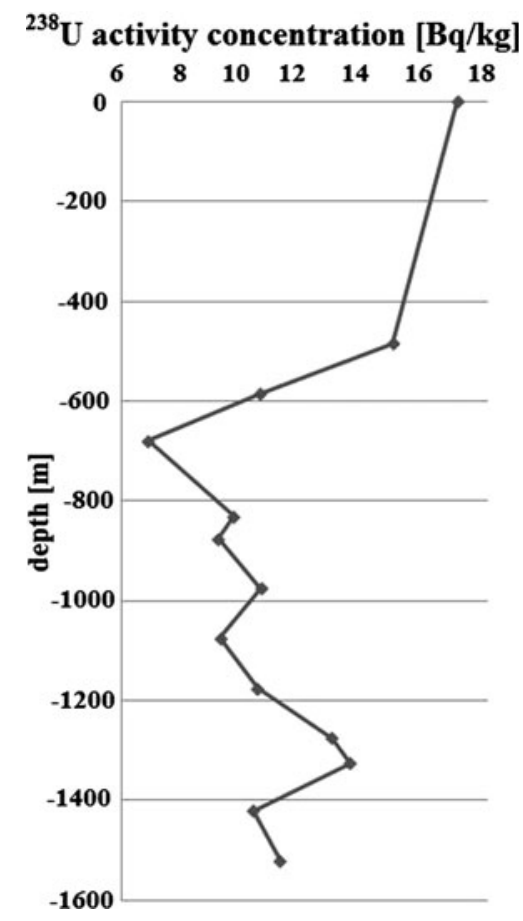

Fig. 5 Uranium-238 activity concentration profile for the Poddebice bore-hole

In thermal groundwater from Poddebice, the activity ratio of ${ }^{234} \mathrm{U} /{ }^{238} \mathrm{U}$ was the lowest with an average value $0.935 \pm 0.021$, and practically does not change seasonally.

In deep well water exploited from $70 \mathrm{~m}$ below ground level, the uranium isotope activity ratio changed from 0.9 in June to 1.30 in April.

As was mentioned, most groundwater samples have ${ }^{234} \mathrm{U} /{ }^{238} \mathrm{U}$ activity ratio above 1 . An excess of ${ }^{234} \mathrm{U}$ is explained by $\alpha$-recoil of ${ }^{234} \mathrm{Th}$ into solution and by preferential leaching of ${ }^{234} U$ from soil [22, 23]. However this phenomenon plays a role for water reservoirs with adjacent rock with a higher concentration of uranium, for example granitic minerals. It should be mentioned that $\alpha$-recoil mechanism is efficient when dissolution rates are low and the residence times of adjacent water in contact with the rock are very long. Such conditions do not exist in the case of Poddebice thermal groundwater, which has a temperature of about $60^{\circ} \mathrm{C}$, and a sandy soil environment with very low uranium content. The profile of the uranium activity concentration in the Poddebice bore-hole is shown in Fig. 5.

As is evident from Fig. 5, uranium surface soil activity is equal to $17 \mathrm{~Bq} / \mathrm{kg}$, whereas for the deeper sandy geological formation, which surround the thermal groundwater reservoir, this activity concentration decreases to very low values of $\approx 11 \mathrm{~Bq} / \mathrm{kg}$.

In this case, the dissolution rate of both uranium isotopes is higher and the input of ${ }^{234} \mathrm{U}$ recoil directly to the
Table 3 Activity concentration and activity ratio of uranium isotopes in the water samples from central Poland

\begin{tabular}{cllll}
\hline & & \multicolumn{2}{c}{ Activity $\left(\mathrm{mBq} / \mathrm{dm}^{3}\right)$} & \\
\cline { 3 - 4 } & & ${ }^{234} \mathrm{U} /{ }^{238} \mathrm{U}$ \\
Geothermal & Mszczonow & $13.32 \pm 0.26$ & $15.98 \pm 0.29$ & \multirow{2}{*}{0.83} \\
reservoir & Skierniewice & $<0.013$ & $<0.013$ & - \\
& Uniejow & $0.39 \pm 0.04$ & $0.54 \pm 0.04$ & 0.75 \\
& Poddebice $^{\mathrm{a}}$ & $0.12 \pm 0.03$ & $0.13 \pm 0.03$ & 0.94 \\
\hline
\end{tabular}

${ }^{a}$ Average from ten month in 2011 year

solution is negligible. However, because of very low uranium concentration in the surrounding soil, leachable uranium radionuclides in the time scale of these processes (the dozen thousands of years) are exhausted and there is no renewal of material (uranium) exposed to water weathering. Then, such water would be expected to evolve to have values of ${ }^{234} \mathrm{U} /{ }^{238} \mathrm{U}$ ratio below unity even up to 0.3 as presented in models by Anderson et al. [24] or Rihs et al. [25].

This data clearly show lack of any water transport from the surface water to thermal groundwater reservoir. However, such transfer from the Ner river to the underground municipal water is possible.

Uranium activity concentration in thermal groundwater samples from Central Poland

Lower values of ${ }^{234} \mathrm{U} /{ }^{238} \mathrm{U}$ activity ratio were also observed for the geothermal waters in other places in Central Poland. The results are presented in Table 3.

As shown in Table 3 , the activity concentration of ${ }^{234} \mathrm{U}$ and ${ }^{238} \mathrm{U}$ in water samples varied in a wide range, from $<0.013$ to $16.84 \mathrm{mBq} / \mathrm{dm}^{3}$ and from $<0.013$ to $45.47 \mathrm{mBq} /$ $\mathrm{dm}^{3}$, respectively. The highest uranium activity concentrations were measured in thermal groundwater from Mszczonow and Cieplice, whereas the lowest uranium activities were found in thermal ground water from Uniejow and Poddebice.

The values of ${ }^{234} \mathrm{U} /{ }^{238} \mathrm{U}$ activity ratio below 1 confirm basically the same hydro geochemical conditions for all these thermal groundwater reservoirs in Central Poland. Similarly, lower values of uranium activity ratio for most geothermal waters are reported by Osmond and Cowart [4].

\section{Conclusions}

${ }^{234} \mathrm{U}$ and ${ }^{238} \mathrm{U}$ activity concentrations were determined in the water samples (river water, deep well water and thermal groundwater) collected from Central Poland. Uranium activity concentrations in the analyzed waters varied in a 
wide range. On the basis of the measured values, the uranium activity ratio $\left({ }^{234} \mathrm{U} /{ }^{238} \mathrm{U}\right)$ was calculated. In deep well water and river water, uranium activity ratio $\left({ }^{234} \mathrm{U} /{ }^{238} \mathrm{U}\right)$ was higher than 1 (from 1.06 to 1.20 ), while in thermal groundwater it was lower than 1 (from 0.75 to 0.95 ). A comparison of the average uranium isotopic ratio in the well water from Poddebice (1.06) and river water from the Ner (1.09) show possible infiltration of surface water to this reservoir.

The lower ${ }^{234} \mathrm{U} /{ }^{238} \mathrm{U}$ ratios in the geothermal water are caused by the fact that the majority of both uranium isotopes come from the uranium present in low concentrations in the adjacent rocks and its relatively quick dissolving at higher temperatures leads to its exhausting from the surface layer of rocks contacting with water. Therefore, the input of the recoil ${ }^{234} \mathrm{U}$ atoms is negligible. The remarkably lower ${ }^{234} \mathrm{U} /{ }^{238} \mathrm{U}$ data for thermal groundwater in the Poddebice region in comparison with data for surface and well water in this region, clearly show lack of any water transport from the surface water to this reservoir.

Acknowledgment We gratefully acknowledge the financial support by the Protection of the Environment and Water Management Fund in Łódź and Polish Ministry of Higher Education (KBN) grant 1341/B/ H03/2011/40.

Open Access This article is distributed under the terms of the Creative Commons Attribution Noncommercial License which permits any noncommercial use, distribution, and reproduction in any medium, provided the original author(s) and source are credited.

\section{References}

1. Camacho A, Devesa R, Valles I, Serrano I, Soler J, Blazquez S, Ortega X, Matia L (2010) Distribution of uranium isotopes in surface water of the Llobregat river basin (Northeast Spain). J Environ Radioact 101:1048-1054

2. Skwarzec B, Boryło A, Strumińska D (2002) ${ }^{234} U$ and ${ }^{238} U$ isotopes in water and sediments of the southern Baltic. J Environ Radioact 61:345-363

3. Plater AJ, Ivanovich M, Dugdale RE (1992) Uranium series disequilibrium in river sediments and waters: the significance of anomalous activity ratios. Appl Geochem 7:101-110

4. Osmond JK, Cowart JB (1992) Groundwater. In: Ivanovich M, Harmon RS (eds) Uranium-series disequilibrium. Applications to earth, marine and environmental sciences, 2nd edn. Oxford Science Publications, Oxford

5. Fleischer RL (1980) Isotopic disequilibrium of uranium: alpharecoil damage and preferential solution effects. Science 207:979-981

6. Pietrzak-Flis Z, Kamińska I, Chrzanowski E (2004) Uranium isotopes in waters and bottom sediments of rivers and lakes in Poland. Nukleonika 49(2):69-76

7. Bellis D, Ma R, Bramall N, McLeod CW (2001) Airborne emission of enriched uranium at Tokai-mura, Japan. Sci Tot Environ 114:283-286
8. Mas JL, Ma R, McLeod C, González-Labajo J, Cox A, Watson P (2006) Determination of ${ }^{234} U /{ }^{238} U$ isotope ratios in environmental waters by quadrupole ICP-MS after U stripping from alpha-spectrometry counting sources. Anal Bioanal Chem 386:152-160

9. Zoriy MV, Halicz L, Ketterer ME, Pickhartd C, Ostapczuk P, Becker JS (2004) Reduction of $\mathrm{UH}^{+}$formation for ${ }^{236} \mathrm{U} /{ }^{238} \mathrm{U}$ isotope ratio measurements at ultratrace level in double focusing sector field ICP-MS using $\mathrm{D}_{2} \mathrm{O}$ as solvent. J Anal Atom Spectrom 19:362-367

10. UNESCAR (2000) United Nations Committee on the Effects of Atomic Radiation. Sources, Effects, and Risks of Ionizing Radiation. United Nations, New York

11. Hossain MMM, Ohde S (2002) Uranium in pore water from coastal sediments determined by chemical activation analysis. J Radioanal Nucl Chem 251(2):333-336

12. Vesterbacka P (2005) ${ }^{238} \mathrm{U}$-series radionuclides in Finnish groundwater-based drinking water and effective doses. STUK, Helsinki

13. Rathore DPS (2008) Advanced in technologies for the measurement of uranium in divorce matrices. Talanta 77:9-20

14. Hou X, Roos P (2008) Critical comparison of radiometric and mass spectrometric method for the determination of radionuclides in environmental, biological and nuclear waste samples. Anal Chim Acta 608:105-139

15. Becker JS (2005) Inductively coupled plasma mass spectrometry (ICP-MS) and laser ablation ICP-MS for isotope analysis of longlived radionuclides. Int J Mass Spectrom 242:183-195

16. Grabowski P, Długosz M, Szajerski P, Bem H (2010) A comparison of selected natural radionuclide concentrations in the thermal groundwater of Mszczonów and Cieplice with deep well water from Łódź city, Poland. Nukleonika 55(2):181-185

17. Skwarzec B, Strumińska DI, Boryło A (2003) Radionuclides of ${ }^{210} \mathrm{Po},{ }^{234} \mathrm{U}$ and ${ }^{238} \mathrm{U}$ in drinking bottled mineral water in Poland. J Radioanal Nucl Chem 256(2):361-364

18. Eikenberg J, Tricca A, Vezzu G, Bajo S, Ruethi M, Surbeck (2001) Determination of ${ }^{228} \mathrm{Ra},{ }^{226} \mathrm{Ra}$ and ${ }^{224} \mathrm{Ra}$ in natural water via adsorption on $\mathrm{MnO}_{2}$-coated discs. $\mathrm{J}$ Environ Radioact 54:109-131

19. Bem H, Olszewski M, Kaczmarek A (2004) Concentration of selected natural radionuclides in the thermal groundwater of Uniejow. Nukleonika 49(1):1-5

20. Jia G, Torri G, Ocone R, Di Lullo A, De Angelis A, Boschetto R (2008) Determination of thorium isotopes in mineral and environmental water and soil samples by a-spectrometry and the fate of thorium in water. Appl Radiat Isot 66:1478-1487

21. Skwarzec B, Kabat K, Astel A (2009) Seasonal and spatial variability of ${ }^{210} \mathrm{Po},{ }^{238} \mathrm{U}$ and ${ }^{239+240} \mathrm{Pu}$ levels in the river catchment area assessed by application of neural-network based classification. J Environ Radioact 100:167-175

22. Kigoshi K (1971) Alpha-recoil thorium-234: dissolution into water and the uranium-234/uranium-238 disequilibrium in nature. Science 173:47-48

23. Fleischer RL, Raabe OG (1978) Recoiling alpha-emitting nuclei. Mechanisms for uranium series disequilibrium. Geochem Cosmochim Acta 42:973-978

24. Andersen MB, Erel Y, Bourdon B (2009) Experimental evidence for ${ }^{234} \mathrm{U}^{238} \mathrm{U}$ fractionation during granite weathering with implications for ${ }^{234} \mathrm{U} /{ }^{238} \mathrm{U}$ in natural waters. Geochem Cosmochim Acta 73:4124-4141

25. Rihs S, Condomines M, Poidevin JL (2000) Long-term behavior of continental hydrothermal systems: U-series study of hydrothermal carbonates from the French Massif Central (Allier Valley). Geochem Cosmochim Acta 64(18):3189-3199 